\title{
Organizational confidence and its role in improving the performance of staff Field research for a sample of Samaraa University and the Samaraat University staff
}

\author{
Omar Azeez Abbas ${ }^{1}$, Abdulrahman Kareem Mohammed Shamani ${ }^{2}$ \\ ${ }^{1,2}$ University of Samarra
}

Article History: Received: 11 January 2021; Accepted: 27 February 2021; Published online: 5 April 2021

\begin{abstract}
the research is to learn about organizational confidence and its role in improving the performance of staff and to achieve this goal, the researchers have found through the research hypothesis and its change of organizational confidence in its dimensions (confidence in senior management, confidence in the direct president, trust with co-workers). The second change is to improve the performance of staff, where the research sample consisted of 50 staff members at the university and college levels. The most important results were the lack of delegation of authority, participation in decision-making and insufficient attention to work requirements The experience of the management of the system is that the system is not only a function of the system, but also a function of the system. The 2 -way

Keywords: Organizational confidence, improving worker performance
\end{abstract}

\section{Introduction}

The subject of organizational trust is an important issue in the area of business management in general and in human resources management, especially as it has a key and effective role in increasing the efficiency of organizations and improving the performance of their staff as it is the key to the success of work and development in managing the workforce. It helps build personal relationships, support free speech, participate in teams and make decisions, so organizations need to consider and focus on organizational confidence, In this context, we seek to diagnose the role of organizational confidence in improving the performance of staff of a number of employees working at the University of Samarra.

\section{A. Research methodology}

The study of the study is a study of the study of the study of the study of the study of the study of the study of the study of the study of the study of the study of the study of the study of the study of the results

\section{B. Search problem}

Many university workers face lack of interest, lack of freedom of expression, participation in decisionmaking, work problems, poor organizational relationships between employees and heads of work, and this is reflected negatively in the performance of employees, which is what the problem of research is by highlighting (Organizational confidence and its role in improving the performance of staff of the University of Samarra.)

\section{C. the importance of research}

The importance of research shows the importance of the variables it has addressed and represents recent topics that are the general thrust of the organizations that are concerned with improving their employees' performance. It also highlights the importance of research by providing a set of guidelines for universities to enable organizational confidence to improve their employees' performance.

\section{Research objectives}

The search seeks to achieve the following objectives:

1. Identify the role of organizational trust and how it can improve the performance of the university staff in question.

2. Provide a range of appropriate solutions and recommendations for the activation of the role of organizational trust for the purpose of improving the performance of the staff of the University in question

\section{C. the search hypothesis}

The adoption of organizational trust in organizations with different dimensions makes them stand out, regulatory trust achieves job stability and raises employee performance indicators.

\section{E. Data collection method}

The data collection researcher has relied on the following methods:

1. Theoretical sources of books, letters and scientific research, as well as journals, scientific conferences and Internet sites.

2. Interviews. 
3. The questionnaire, which contained two parts of the statements, targeted general information, while part two revealed information about organizational confidence to the staff to learn about the role of organizational confidence in improving the performance of the university and college staff.

\section{F. Statistical methods used in data analysis}

The investigator used the correlation coefficient to show the nature of the relationship between search variables.

\section{Y. Search}

The total sample of the research was 50 out of a total of 467 employees of the entire research community, who were staff members of the university and college departments.

\section{Theoretical side}

\section{A. The concept of organizational trust}

Organizational confidence is the same as all management concepts it is difficult to agree on a concept by researchers.it is multilevel because it is the output of a set of interactions (joint work, staff, organizational interventions) at all organizational levels (God's grandstanding, 2009). It was defined as a critical condition for the formation and strength of human relations (Bagraim\&Tlime,2007) and defined it (Tai,2007) as the individual's faith in the aims, decisions and policies of the organization, the organizational leader and all individuals working with him in the organization, reflecting the individual's satisfaction and commitment to the organization. She also knew her (Kazem, 2004) as the individual's belief in the fairness of the organization and its reliance on it to demonstrate good governance when making business decisions and relying on supervisor and co-workers to reflect the individual's loyalty to the organization.

\section{B. The importance of organizational trust}

Building and building organizational confidence in the Organization is a fundamental measure that ensures interaction and mutual exchange between all levels the purpose of accomplishing the various tasks of the Organization, thus contributing to its success. Its failure to activate it reflects negative results on the Organization and some researchers have indicated that several key points can highlight the importance of organizational confidence in the Organization, including what he has emphasized (Al Douri and Saleh, 2009; The Lord's earthly, 2009) and it is as follows:

1. Regulatory trust is a key factor in reducing regulatory complexity.

2. Regulatory trust is a strategic asset that is a source of competitive advantage for organizations.

3. Regulatory confidence plays a key role in cost worries.

4. Organizational confidence is an element of the social capital of the Organization.

5. Organizational confidence reduces work problems, increases job satisfaction, and helps develop new ideas.

6. Regulatory confidence contributes to a lower turnover rate and improved personal relationships among workers.

\section{Organizational confidence-building methods}

Many researchers believe that there are several fundamental and fundamental ways to build organizational trust in organizations, including the following (Morsi, 2010):

1. Managers should respect the views of the workers and delegate some sufficient powers.

2. Support staff ideas by managers and make suggestions.

3. To open channels of communication between managers and employees to be informed of decisions and policies.

4. Use of justice, objectivity and non-alignment by managers in assessing the performance of workers.

5. Work on the application of successful management by managers.

The organization also emphasized some of the most important basic steps that the organization must take in building organizational confidence, including:

1. Avoid using force in dealing.

2. Work on training workers to take responsibility.

3. Optimize time and focus on problem solving.

4. Avoid looking for personnel errors and confirm that the error does not repeat.

5. Work to support workers, give them training opportunities, encourage them and encourage them to do business.

6. Simplify and not complicate work procedures. 
The research finds that not taking into account the role of organizational trust in the organization by its administrative levels may expose it to significant losses in its human and social capital, which may be lost by its competitive advantage.

\section{Dimensions of organizational confidence .}

Many researchers have agreed on a set of basic dimensions of regulatory trust, including (Jad al-Rab, 2009; Cirnis, 2006; Saudi Arabia, 2005; Ruashda, 2004; Kasabah,1996), which is (trust in senior management, trust the direct president, trust colleagues) and which is referred to by both (Abdallah,2018; Abushaich, 2013).

1. Trust in the Supreme Administration.

2. Confidence in the direct president.

3. Trust co-workers.

\section{Improving the performance of workers .}

A. the concept of performance improvement

There is no doubt that the process of improving the performance of strategic operations in business organizations is because they are based on the achievement of targeted performance rates and standards, the identification and growth of strengths, the identification of deficiencies and weaknesses, and the attempt to remedy them. Improving performance is not an end in itself but a necessary tool for continuous development both at the level of individual performance and in the overall performance of the organization (Jad al-Lord, 2016). Performance is defined as the levelatwhich an individual worker worksin terms of quantityand qualityof workprovidedby him (method, 2004), as he/she knew (Brown\&Harvey,2006), is the result of an action or activity.

B. the importance of improving performance

Improving performance is of great importance to all organizations because the system's ability to stabilize, grow and survive depends on its performance. It is linked to the existence, dissociation, and collapse of regulation, and is a core concept that has been of particular importance to management thinking and business organizations, since it is linked to the organization's ability to achieve its goals (Jad, Gad, 2016). He stressed several key points on which performance improvement is important:-

1. The process of improving the performance of employees helps to create a competitive advantage for the organization through innovation and innovation.

2. The process of improving performance helps to detect strengths and weaknesses in the business.

3. The process of improving performance helps to increase quality with the inputs and outputs of the production process.

4. Improved performance helps organizations quickly achieve the goals set.

5. The process of improving performance helps reduce work turnover while reducing costs and streamlining expenditures.

C. Essential elements for improving performance

1. Performance consists of a set of elements, the most important of which are (Smil, 2011, Akasha, 2008):-

2. Knowledge of job requirements includes general knowledge, technical, professional skills, general background on the job and related fields.

3. The quality of work is how well an individual knows about his or her work and what she has, skills, skill, skill, organization, and work without error.

4. The amount of work done is how much work the employee can do in normal working conditions and how fast this achievement is.

\section{Applied Framework: Statistical analysis of resolution results}

The study's sample of the study applied to a sample of Samaraa University staff with its facilties and departments was obtained by knowing the 50 sample staff members that the Samaraa University staff was (808) affiliated with the number of employees (467).

1. Data collection tools for applied research were designed for the purpose of the search and distributed to the sample of 50 staff members. The resolution axes included three main questions distributed to (15) subquestions and 42 were answered.

2. Sample Search: Because the research community is homogeneous, the researcher has relied on a class sample and as in Appendix 1. 
3. Consistency and stability of resolution: Done through Alpha stabilization and measurement: From the table below we note the value of the Alpha stabilization and the Annex 1 measurement that is (0.929) and is very high, which indicates internal consistency between the questions in the Appendix 2 questionnaire.

4. Natural distribution test: It is very important that research data follow the normal distribution, which can be observed by testing COLMOCAREF-Smirnov through Appendix 3 below We note that the value of morale is equal to (0.000) and that means data follows the normal distribution.

\section{A. Sample size, mean, and standard deviation:}

1. From table (1) below, we observe the sample size, the mean, and the standard deviation of each of the study axes (subaxes). In the main areas of study we find the average number of arithmetic averages, the largest of which is the average confidence in co-workers (4.25) and the lowest confidence in senior management (3.74) and as below, the answers are also consistent and homogeneous in the trust of co-workers

\begin{tabular}{|c|c|c|}
\hline Standard deviation & Arithmetic mean & Main Study axles \\
\hline 1.017 & 3.74 & $\begin{array}{c}\text { Trust in senior } \\
\text { management }\end{array}$ \\
\hline 0.969 & 3.94 & Trust the direct president \\
\hline 0.736 & 4.25 & Trust co-workers \\
\hline
\end{tabular}

In detail, the answers to trust in senior management, which recorded the results, achieved the highest arithmetical average of 3.88 in a question, is senior management providing the information required to work in this dimension or activity, A high homogeneity is also shown in the sample's answers through a standard deviation of 0.91 and in the second sequence. The lowest average (3.61) for applying the highest management of the system to all employees without discrimination and a clear disagreement was expressed among the sample members through the results of their poorly obtained answers in the question of senior management's confidence in its ability to meet its obligations and a standard deviation (0.76).

Table 1: Arithmetic averages and standard deviations of study sample responses for question 1

\begin{tabular}{|c|c|c|c|}
\hline \multicolumn{2}{|c|}{} & \multicolumn{2}{|c|}{ Threshing axes } \\
Standard & $\begin{array}{c}\text { Arithmeti } \\
\text { c mean }\end{array}$ & $\begin{array}{c}\text { Sampl } \\
\text { e size }\end{array}$ & \begin{tabular}{c} 
Trust in senior management \\
\hline 0.7624
\end{tabular} \\
3,8333 & 42 & $\begin{array}{c}\text { Senior management is confident that it can meet } \\
\text { its commitments. }\end{array}$ \\
\hline 0.9183 & 3.7143 & 42 & $\begin{array}{c}\text { Clear management policies followed by senior } \\
\text { management. }\end{array}$ \\
\hline 0.9160 & 3.8810 & 42 & $\begin{array}{c}\text { Senior management provides the information } \\
\text { that the business requires. }\end{array}$ \\
\hline 1.1617 & 3.6667 & 42 & $\begin{array}{c}\text { Senior management is concerned with workers, } \\
\text { innovators and innovators }\end{array}$ \\
\hline 1.2678 & 3.6190 & 42 & $\begin{array}{c}\text { The system applies to all employees without } \\
\text { discrimination }\end{array}$ \\
\hline
\end{tabular}

The nature of the accounting circles for the questions of the first axis is also clearly illustrated by the following figures: Figure 1. The average arithmetic of (3.83) is the confidence of the senior management in its ability to meet its obligations and form 2. The average arithmetic of (3.71) Clear policies followed by senior management and figure 3 senior management provides the information required to work with my account center (3.88), Figure 4 Senior Management is concerned with the employees, innovators and innovators being distinguished by my account center (3.66), and Figure 5 reflects the system's application to all employees without distinction as to a mathematical medium of (3.61).

Figure (2) Figure (1) 


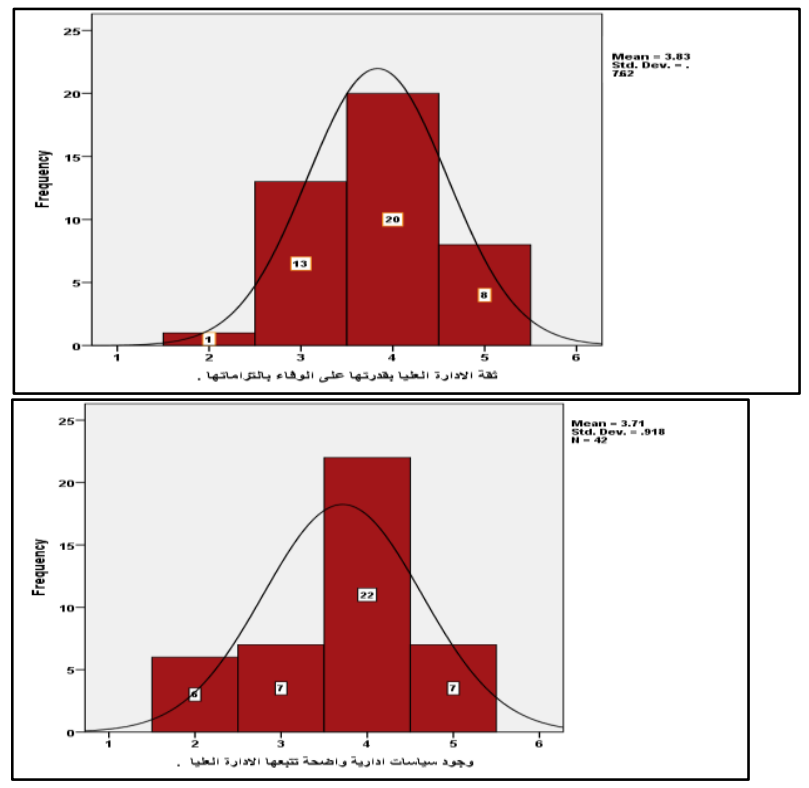

Figure (4) Figure (3)

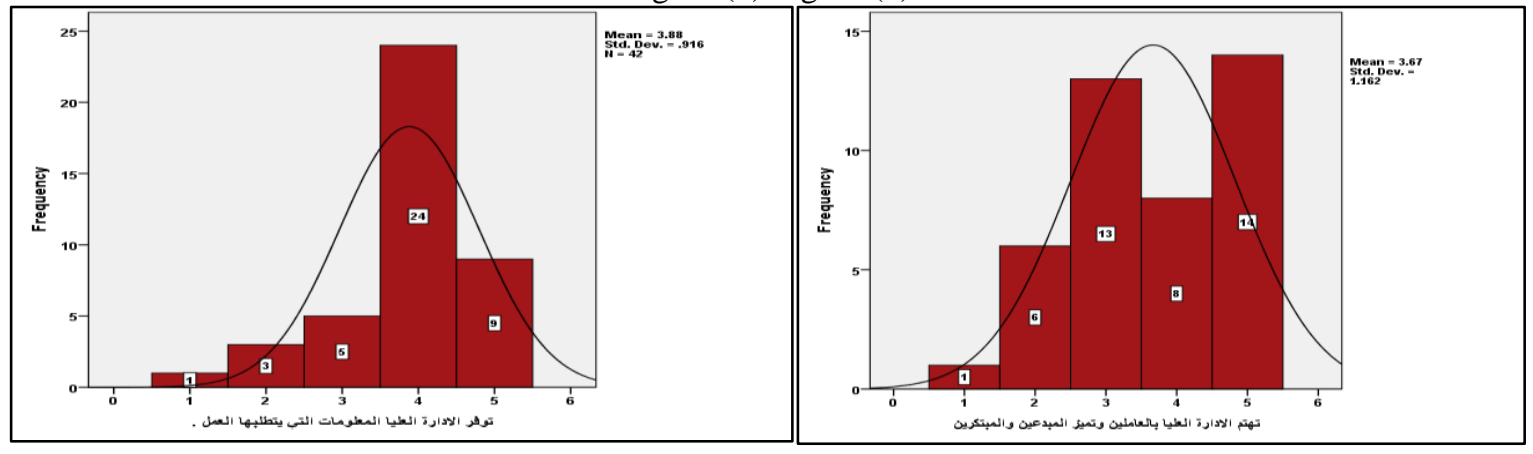

Figure (5)

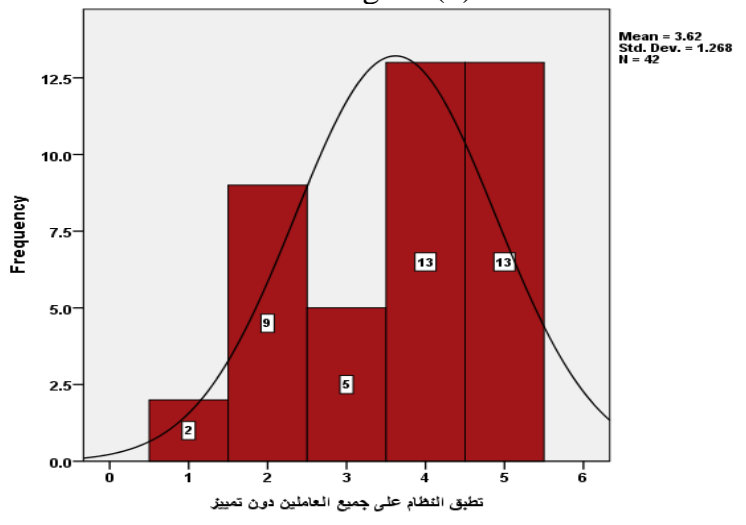

2. From table 2 below, responses to the direct leader have clearly marked a divergence as the results have been scored at a higher arithmetical average of 4.16 in interest of ideas that can contribute to improved performance, and show the highest homogeneity in the sample responses through a standard deviation of 0.85 and came in the first sequence. The lowest average (3.78) for delegating some powers through the results of their answers, but for homogeneity, the answers to the question were first, which included attention to ideas that could contribute to improving performance and which were poorly obtained (0.85) and indicate agreement between the sample views.

Table 2: Arithmetic averages and standard deviations of responses for the study-on-question 2.

\begin{tabular}{|r|c|c|c|}
\hline \multicolumn{2}{|c|}{ Trust the direct president } \\
\hline $\begin{array}{c}\text { Standar } \\
\text { d deviation }\end{array}$ & $\begin{array}{c}\text { Arithmetic } \\
\text { mean }\end{array}$ & $\begin{array}{c}\text { Sampl } \\
\text { e size }\end{array}$ & Trust the direct president \\
\hline
\end{tabular}




\begin{tabular}{|c|c|c|c|}
\hline 0.8530 & 4.1667 & 42 & $\begin{array}{l}\text { Interest in ideas that can contribute to } \\
\text { improved performance. }\end{array}$ \\
\hline 0.9615 & 3.9524 & 42 & $\begin{array}{l}\text { Listen to the views of the staff with a chest } \\
\text { capacity. }\end{array}$ \\
\hline 1.0215 & 3.9286 & 42 & Climate and work environment. \\
\hline 0.8705 & 3.7857 & 42 & Delegates some powers. \\
\hline 1.1169 & 3.8571 & 42 & Justice is done among the workers. \\
\hline
\end{tabular}

The figures reflect the nature of the computational circles of the second axis questions Figure 6 an arithmetic mean of (4.17) interest in ideas that can contribute to improving performanceand figure 7 mean arithmetic 3.95) listening to the views of the two-factor chest and figure 8 reflecting the climate and the environment suitable for working in the middle of my account (3.92) Figure 9 authorizes some powers to my account center (3.78) and Figure 10 reflects the justice of my staff in my middle account (3.85).

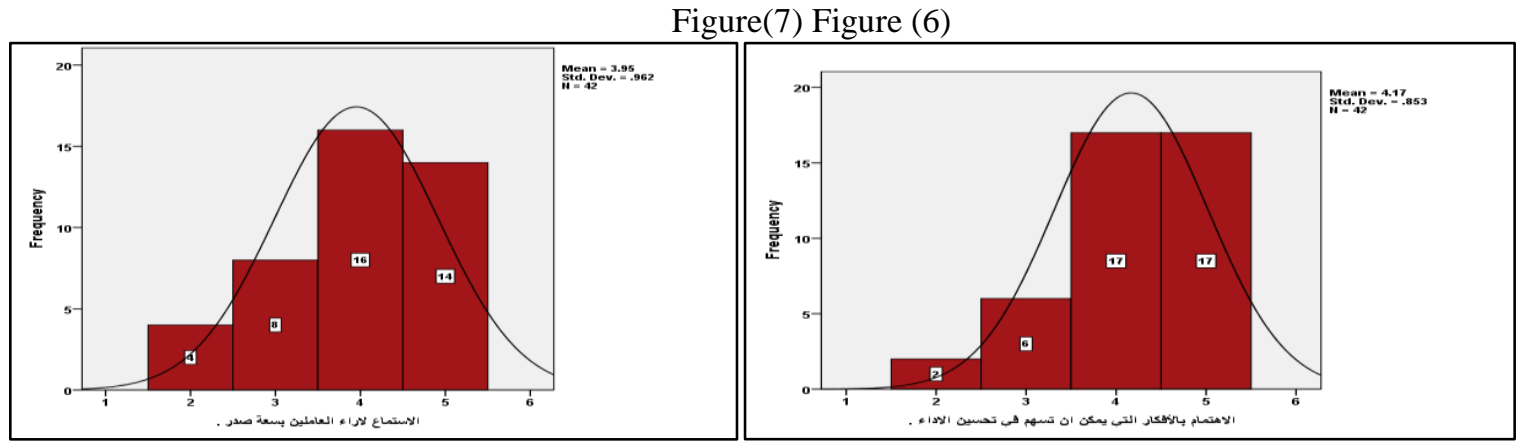

Figure(9) Figure (8)

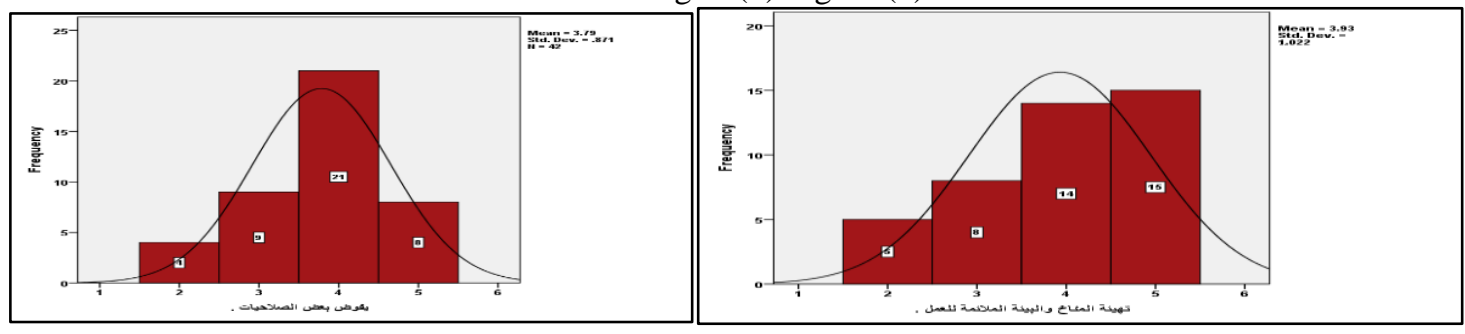

Figure(10)

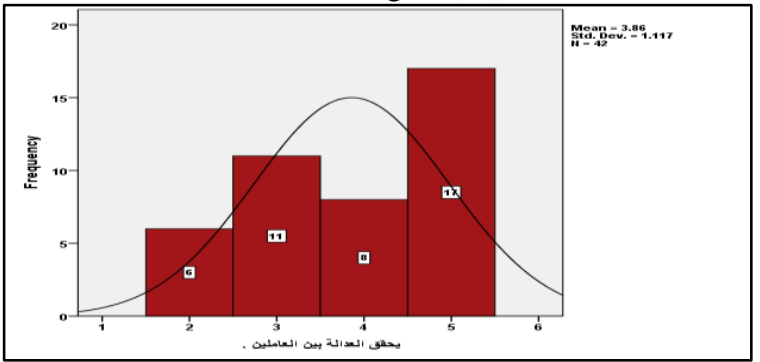

3. From table 3 below, answers to colleague confidence have converged on answers where the results are the highest arithmetical average of 4.38 in the answers to the question of good relationships with employees. The highest homogeneity in the sample's responses is the standard deviation of 0.56 but the answer to the question is whether there is an exchange of work information, reflecting a lack of agreement between the sample's answers and the lowest average of 4.09 for the single team's genus across the results of their answers

Table 3: Arithmetic averages and standard deviations of the sample responses for the study population on question 3.

\begin{tabular}{|c|c|c|c|}
\hline \multicolumn{3}{|c|}{} & \multicolumn{2}{c|}{ Trust co-workers } \\
\hline 0.7169 & 4.2143 & 42 & Exchange of trust between employees. \\
\hline 0.9579 & 4.0952 & 42 & Working in the spirit of one team. \\
\hline 0.7213 & 4.3333 & 42 & $\begin{array}{c}\text { Collaborate with workers to improve work } \\
\text { performance. }\end{array}$ \\
\hline
\end{tabular}




\begin{tabular}{|c|c|c|c|}
\hline 0.6608 & 4.3810 & 42 & Establish good relationships with employees. \\
\hline $\mathbf{0 . 5 6 4 6}$ & 4.2143 & 42 & There is an exchange of business information. \\
\hline
\end{tabular}

The average third axis of trustee trust in its five questions is reflected in the graphs Figure 11 arithmetic mean 4.21 Staff-employee trust and form 12 average arithmetic 4.09 Team-style work and form 13 reflects staff collaboration to improve work performance in the middle of my account 4.33 and Figure 14 good relationships With staff in my account center 4.38 and Figure 15 there is an exchange of business information in my account center 4.21

Figure(12) Figure(11)

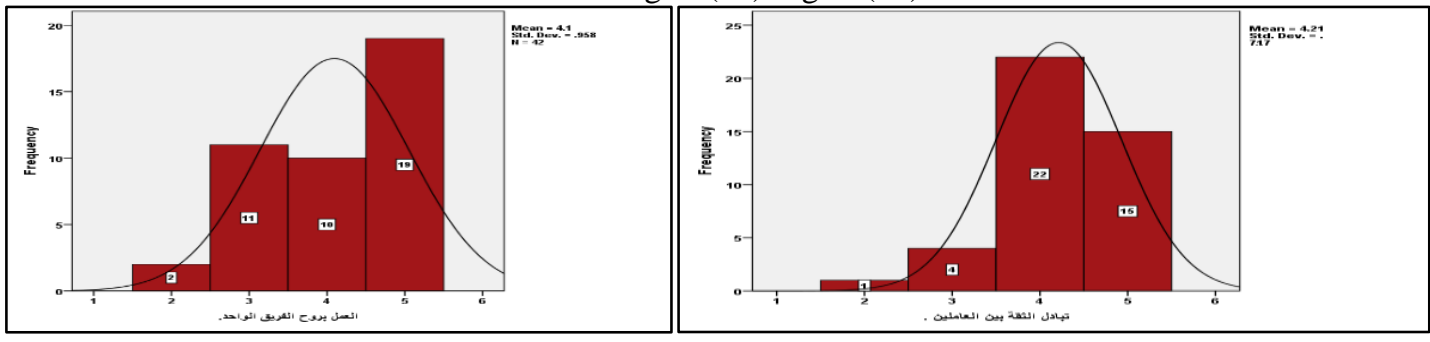

Figure(14) Figure(13)

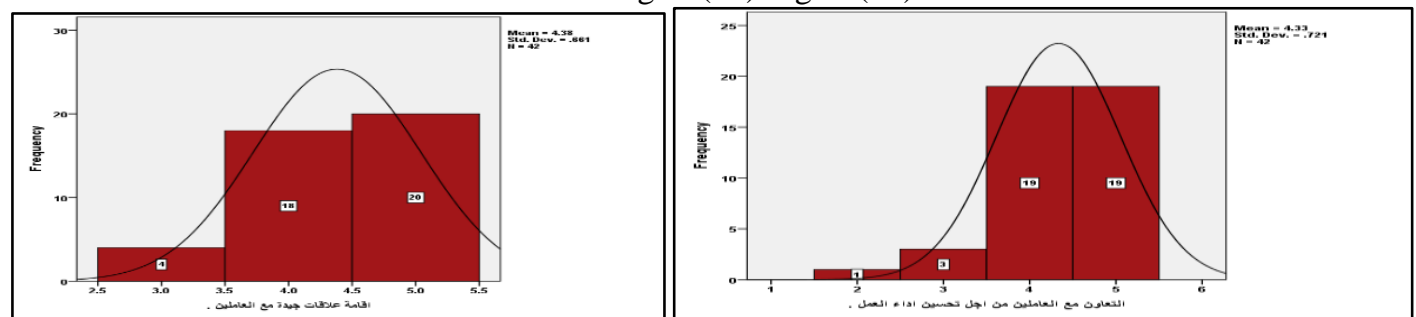

Figure(15)

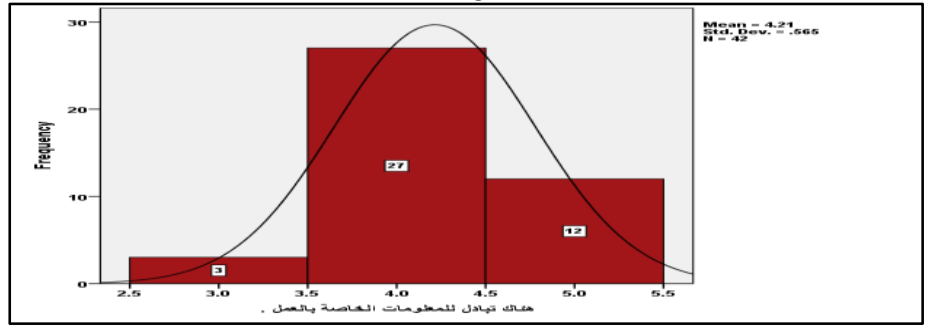

B. simple correlation coefficient (Pearson)

The table below shows the value of Pearson's simple correlation coefficient between the study axes (key axes) and the emotional relationship between variables, where we note that the most powerful correlation was between the first variable confidence in senior management and the second variable confidence in the direct president (0.547). The relationship between variables is significant, which means that confidence in senior management has a significant influence on both the direct and the trust of the direct president and the confidence of co-workers and vice versa

Table (4): Pearson correlation coefficient results for study variables

\begin{tabular}{|c|c|c|c|c|}
\hline \multicolumn{5}{|c|}{ Correlation coefficient } \\
\hline $\begin{array}{l}\text { Trust co- } \\
\text { workers }\end{array}$ & $\begin{array}{l}\text { Trust the direct } \\
\text { president }\end{array}$ & $\begin{array}{l}\text { Trust in senior } \\
\text { management }\end{array}$ & $\begin{array}{l}\text { Correlation } \\
\text { coefficient }\end{array}$ & Threshing axes \\
\hline 0.386 & 0.547 & 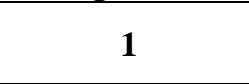 & Pearson Coralization & $\begin{array}{l}\text { Trust in senior } \\
\text { management }\end{array}$ \\
\hline 0.000 & 0.000 & & SIG. (2-tails) & Morale \\
\hline 0.357 & 1 & 0.547 & Pearson Coralization & $\begin{array}{c}\text { Trust the direct } \\
\text { president }\end{array}$ \\
\hline 0.000 & & $\mathbf{0 . 0 0 0}$ & SIG. (2-tails) & Morale \\
\hline 1 & 0.357 & 0.386 & Pearson Coralization & $\begin{array}{c}\text { Trust co- } \\
\text { workers }\end{array}$ \\
\hline & 0.000 & 0.000 & SIG. (2-tails) & Morale \\
\hline
\end{tabular}




\section{Results}

1. The results of the survey at Samarra University showed that confidence in senior management is very positive in improving the performance of the staff by the strong correlation between the 0.547 organizational confidence dimensions, which represent the strength of the first dimension, confidence in senior management over other dimensions.

2. There is a weakness in the delegation of authority to staff and the lack of opportunity to express opinions and participate in decisions on work, reflecting a negative impact on improving performance in the university presidency and its mandates.

3. There is also a weakness in the exchange of labor information and workers' relations among themselves, reflecting the decline in the confidence of working in a team spirit, and the results show that the system is not applied to all workers with little attention to outstanding and creative workers.

4. The results showed a lack of clear management contexts and policies by university departments, reflecting a low level of performance and a lack of full knowledge of the demands of the staff..

\section{Suggestions}

1. Through the above findings, the existence of organizational trust between departments at all levels and between employees should be considered for the purpose of creating a working environment through which performance is achieved.

2. To work on delegating powers to employees and giving them full confidence in the expression of opinion and participation in decisions on work.

3. To create a working environment, to ensure working relationships between employees, to give them confidence to exchange information about work, to apply the system to all, and to value the efforts of innovators and their distinguished people.

4. To promote clear management policies by the university departments, fully clarifying the work requirements of the staff for the highest level of performance.

\section{References}

3. Gad Lord, Syed Muhammad (2009), Organizational Ethics and Social Responsibility in Modern Business Organizations, Egyptian Books House.

4. Al-Taie, Rana Nasser, (2007), "Leadership Styles and Organizational Confidence and its Impact on Achieving Organizational Commitment An Empirical Study of the Views of a Sample of Managers in Mixed Industrial Sector Companies", Master's Thesis in Business Administration submitted to the College of Administration and Economics, University of Baghdad.

5. Kamal, Ehab (2015) How to be a successful manager, Cairo, Egypt: Dar Al-Kholoud for Publishing and Distribution.

6. Al-Douri, ZakariaMutlaq and Saleh, Ahmad Ali, (2009), Empowerment and Trust Economics Department, Amman, Jordan: Al-Yazouri Scientific House.

7. Al-Saadi, MuayyadNeama 2011)), Contemporary intellectual developments in organizational behavior and human resources management, Amman, Jordan: Al-Warraq Institution for Publishing and Distribution.

8. Al-Serafi, Muhammad (2006), Administrative and Creative Leadership, Alexandria, Egypt: Dar Al-Fikr AlJami'a.

9. Morsi, Nabil Hamed, (2010) The Art of Human Resource Management in Governmental and Private Organizations, Alexandria, Egypt: Modern Arab Office.

10. Al-Kasasbeh, Mohammed Mufdi (1996), "Factors affecting organizational confidence", field study on devices. Jordanian Service, Unpublished Master Degree, University of Jordan, Amman.

11. Saudi Arabia, Musa Ahmed, “(2005) The Relationship between Organizational Confidence and Job Satisfaction among Workers in Jordanian Ministries", Field Study, Administrative Sciences Studies, Amman, Jordan.

12. Al-Rawashdeh, IyadTaha, “(2004) Organizational regression and its effect on organizational confidence among workers in Jordanian public institutions," unpublished Master Thesis, Mu'tah University, Jordan.

13. Abdullah, AsmaaZuhri (2018), Organizational confidence in government schools in the Directorate of Hanin Education and its relationship to the organizational affiliation of teachers from their point of view, Master Thesis in Educational Administration, Al-Quds University, Palestine.

14. Abu Shawish, NisreenGhanem (2013), Determinants of Organizational Confidence and its Effects, An Empirical Study on Workers in the UNRWA - Anwarau, Master of Business Administration, Islamic University, Gaza.

15. Hamdaoui, Wasila (2004), Human Resources Department, Publication Directorate of Alamah University. 
16. Madi, Khalil Ismail, (2014), the quality of the career and its impact on the level of job performance of workers, PhD thesis in Business Administration, Faculty of Commerce, Suez Canal University, Ismailia, Egypt

17. Gad El-Lord, Syed Muhammad (2016), Strategies for Development and Improvement of Performance, Second Edition, Arab Republic of Egypt.

18. Jad El-Lord, Syed Muhammad (2016), Strategic Planning: An Approach to Achieving Competitive Excellence, First Edition, Al-Fajr Publishing House, Cairo

19. Al-Samel, Nasser Ali (2011), "Developing the leadership skills of employees and their relationship to job performance", Master Thesis, Naif University, Saudi Arabia, Riyadh.

20. Okasha, Asaad Ahmed Mohamed (2008), "The Impact of Organizational Culture on the Level of Job Performance", Master Thesis, Islamic University, Gaza, College of Commerce, Department of Business Administration.

21. Brown, D.R \& Harvey, D (2006), An Experiential Approach to Organization Development, (7th ed.), Pearson Prentice Hall, New Jersey, USA.

22. bagraim , jeffrey j , hime ,patricia,(2007),"the dimensionalityof workplace interpersonal trust and its relationship toworkplace affective commitment " ,journal of industrial psychology. 